\title{
TEACHING GRAMMAR THROUGH VISUAL ILLUSTRATION FOR THE UNIVERSITY STUDENTS
}

\author{
Syafryadin ${ }^{1}$ \\ ${ }^{1}$ University of Bengkulu \\ ${ }^{1}$ syafryadin@unib.ac.id
}

\begin{abstract}
Teaching grammar needs to be developed by the lecturer or the teacher. The lecturer must find out an alternative way to build good atmosphere in teaching grammar. Hence, one of the alternative ways is through visual illustration. This study examined the visual illustration towards the students' grammar ability enhancement and the problems of the students in learning grammar and the solution. This study combined quantitative and qualitative method in answering the research questions. The instruments are grammar test and interview guideline. The result showed that visual illustration technique is effective in teaching grammar for students. It can be proved by the result of simple statistic calculation, where the score of significant is lower than $0.05(0.00<0.05)$. Besides, students faced several problems in learning grammar, such as are misuse tenses, misuse modal auxiliary, misuse nominal and verbal sentence, and pronoun. The reason students faced those problems can be caused by the student itself, lecturer and inadequate knowledge.
\end{abstract}

Keywords: Teaching Grammar, Visual Illustration, University Students

\section{INTRODUCTION}

Grammar is a subskill which supports other skills in English. That is why grammar taught at the school and existed in academic setting from junior high school until university. Even though, in Elementary school, grammar is implicitly taught by the teacher. This is based on the curriculum regulation article 9 subarticle 2 and 4 in government regulation of Indonesia number 19 in 2005 which has been issued by ministry of Indonesia education,curriculum in higher education must cover English subject (listening, speaking, reading, writing and other subskills (grammar and vocabulary)) and the content of the curriculum depends on the university itself. Grammar subject from the low until advanced level become problems from the students. Sinka (2009) said that Errors may emerge at the level of single words (e.g. in orthography where affixes, vowel and consonant clusters and inflected forms play an important role). As to the sentence level the problems related to the sequence of words and punctuation marks, and linking simple sentences into compound sentences are the most frequent ones. Discourse mistakes are caused by errors made while connecting sentences and associating them with the rest of the text (Sinka, 2009; Thornbury, 1999).

Related to the theory of students' problems in learning grammar, the researcher did an observation and an interview to the students and the lecturer. The researcher found that most of students were poor in grammar. The students did not know how to distinguish between noun, adjective and verb. Besides, the students were difficult in making sentences by using simple present tense, past tense and future.

Several previous studies were about teaching grammar, but they only anlyzed the dificulties of the students in learning grammar, controversies in teaching grammar and strategies to prevent grammar errorsm teachers' perception to teaching grammar (Uibu, K and Liver, M. 2015, Nazari \& Allahyar, 2012, Singh, 2011, Al-Mekhlafi and Nagaratnam, 2011). However, for the 
effective teaching in teaching grammar, the previous studies just used inductive and deductive teaching which used rules and examples and it made the students bored in the classroom. Therefore, the current study is going to implement visual illustration technique in teaching grammar. know the problems faced by students and its reasons.

\section{Literature Review \\ Definition of Grammar}

Ur (2012:75) stated that grammar is defined as the word s are put together to make correct sentences. It means that grammar is related to the sentence formation. Harmer (2007) defined grammar as the part of accuracy which discussed about the structures. It is supproted by Thornbury (1999) and Gleason and Ratner (2009: 231-269) who said that Grammar is a set of rules that explores the forms and structures of sentences that can be used in a language.

Furthermore, Brown (2004:362) point out that grammar is the system of rules governing the conevntional arrangement and relationships of words in a sentence.

In short, grammar is one of the subskills in English which related to the structures of the sentence or language.

\section{Teaching Grammar}

Teaching grammar is almost the same as teaching other skills in English. There will pre, whilst, and post teaching. Ur (2012:76) revealed out that teaching grammar of foreign language is controversial. Most people agree that knowledge of a language means, among other things, knowing its grammar, but this knowledge may be intuitive and it is not necessarily true that grammatical structures need to be taught as such, or that formal rules need be taught or not. Brown (2004:363) explained appropriate grammar-focusing techniques. Those are (1) embedded in meaningful, communicative contexts, (2) Contribute positively to communicative goals, (3) promote accuracy within fluent and communicative language, (4) do not overwhelm students with linguistics terminology, (4) are as lively and intrinsically motivating as possible.

Furthermore, Brown (2004: 365-368) explained the issues about how to teach grammar 1. Should grammar be presented inductively or deductively?

In most contexts, an inductive approach is more appropriate because

(a) it is more in keeping with natural language acquisition (where rules absorbed subconsciously with litte or no conscious focus)

(b) it conforms more easily to the concept of interlanguage development in which learners progress, on variable timetable, through stages of rule acquisition.

(c) It allows students to get a communicative "feel" for some aspect of language before possibly being overwhelmed by grammatical explanations.

(d) It builds more interistic motivation by allowing students to discover rules rather than being told them

2. Should we use grammatical explanations and technical terminology a CLT classroom? In CLT classes, the use of grammatical explanation and terminology must be appproached with care. Teachers or lecturers could exposure the students by giving (1) the simple explanation and terminology which make them easy to understand about grammar. (2) charts and other visuals whenever possible to graphically depict gramatical relationships. and (3) illustrating with clear explanation. Consequently, the sudents' competence of grammar will incline.

3. Should grammar be taught in separate "grammar only" classes?

The grammar course is explicitly integarated into the total curriculum so that the students can readily relate grammatical pointers to their other work in English. Besides, the rest 
of the curriculum controls the content of the grammar course, and not vice versa. Then, grammar is contextualized in meaningful language use. The course covers as much as possible for specific problems students are experiencing.

4. Should teachers correct grammatical errors?

Teachers should correct the grammatical errors, so the students can know their mistakes in grammar. The students can learn from their mistakes and not to repeat the same mistakes in the future.

\section{Grammar Techniques}

Brown (2004:368-373) mentioned the grammar techniques that can be used in teaching grammar as follows:

\section{Charts}

Charts and graphs are useful devices for practicing patterns, clarifying grammatical relationships, and even for undestanding sociolinguistic and discourse constraints.

2. Objects

Objects can be used as media or technique in teaching grammar because the objects can make the situation in the classroom more alive. Besides, the objetcs do not only live up the context, but also provide kinesthetic, hands-on dimesnion to your teaching.

3. Maps and Drawings

Maps and drawings are media or techniques which can be borught in to the classroom to teach grammar. Maps can stimulate the students' use of prepositional phrases, question forms, imperatives and appropriate discourse for getting someone's attention, asking for direction and etc.

\section{Dialogues}

Dialogues are age old technique for introducing and practicing grammarical points. By using dialogues, the students can learn the grammar and analyze the use of grammar in dialogues

\section{Written text}

Written texts can be used by the lecturer or teacher to teach grammar. The written text are given to the students and the students could identify the grammar in the written texts.

6. Visual illustration

Visual illustration can involve many things from written text, pictures, chart, video and other visual things.

\section{Problems in learning and teaching Grammar}

Several studies had conducted the research on grammar problems. Widianingsing \& Gulo (2016) stated that there are several problems in learning grammar for students namely errors in using tenses, plural markers, articles, and verbs. However, the major errors are in terms of tenses. Iqbal, Akbar \& Ahmad (2017) add the information about the problems in learning and teaching grammar was the lecturer or the teacher because some teachers or lecturers do not have adequate knowledge about the grammar to be taught. Thus, the lecturers were difficult to transfer the knowledge. As a result, it can influence the students' understanding about the grammar lesson. Effendi, Rokhyati, Rachman, Rakhmawati, Peritwi (2017) also found the problems in learning grammar, but it is different from the previous one. The problems faced by students in learning grammar are natural difficulties, mother tongue, students' aspects, lecturers' aspects, and the method and timing aspects. Another study by Handayani \& Johan (2018) who found that the majority problem faced by students in learning grammar is tenses. 


\section{Reasons why students Grammar Problems}

Students had problems in learning grammar because of several reasons. Those are lack of knowledge, time limitation and other causes. Several studies had research on this issue. Ameliani (2019) found several reasons or causes of students' problems in learning grammar, such as tenses, overgeneralization, ignorance of rule restriction, and incomplete application of rules. Besides, Widianingsing \& Gulo (2016) found some reason students had problems in learning, such as poor knowledge, limitation time for learning, lazy to read and less learning sources. In this case, for example, students got problems of tenses because they are lazy to read or have not read the book or less knowledge. It can be also caused by the teacher or lecturer could explain it in good way.

\section{METHOD}

\section{Research Design}

This study used mixed method design which employed an experimental design which used two classes pretest and posttest as quantitative, while the qualitative one is descriptive qualitative. Creswell (2014) stated mixed method is a method that intermingles quantitative and qualitative approach. Besides, he said that experimental design is one of the research methods that examine the technique or strategy. In other words, experimental design is used to test the hypothesis. Moreover, the classes are divided into experimental class and control class. Experimental class was given a treatment, while the control class used a conventional technique in teaching grammar. Ary, et al. (2010) and Fraenkel, Wallen, \& Hyun (2012) stated experimental class can be defined as a class which used the new technique, while the control class used an usual technique in teaching and learning process. Furthermore, descriptive qualitative is one of the methods that describes the phenomenon in the classroom.

\section{Research Setting}

This research was conducted at English Departement of Language and culture faculty, in one of the private universities in Semarang, Central Java, Indonesia. This university is located at Jalan Seteran Dalam No.9. This research started at the end of february until june 2019. It consisted of 16 meetings included pretest and posttest for experimental and control class.

\section{Population and Sample}

The population of this research was all the students of English Department in the second semester in one of the private universities in Semarang. The sample of this study was 60 students from two classes, where 30 students for every class. The technique of getting sample of this research was a purposive sampling.

\section{Instruments}

The instruments of this study were grammar test, observation checklist and interview guideline. Those instruments have been validated by experts. Furthermore, those instruments have been made based on the indicator of the research. Those instruments would be used by researchers to gather the data.

\section{Data Analysis}

The data were analyzed quantitatively and qualitatively. The qualitative data were analiyzed by using summarizing and coding (Heigham \& Robert, 2009), while quantitative data were analyzied by using computer calculation SPSS 22 .

\section{RESULTS AND DISCUSSION}

\section{Results}

The effectiveness of Using Visual Illustration in Teaching Grammar 
1.'Grammar Test

Pre-test and posttest of grammar test are illustrated in table 1 below.

Table 1. Results of pre-test, post-test and t-test

\section{Statistics}

\begin{tabular}{|c|c|c|c|c|c|}
\hline & & PretestCG & PosttestCG & PretestEG & PosttestEG \\
\hline \multirow[t]{2}{*}{ N } & Valid & 30 & 30 & 30 & 30 \\
\hline & Missing & 0 & 0 & 0 & 0 \\
\hline \multicolumn{2}{|l|}{ Mean } & 63.93 & 63.47 & 69.03 & 78.23 \\
\hline \multicolumn{2}{|c|}{ Std. Error of Mean } & 2.730 & 1.892 & 2.600 & 1.789 \\
\hline \multicolumn{2}{|l|}{ Median } & 60.00 & 60.00 & 78.00 & 82.00 \\
\hline \multicolumn{2}{|l|}{ Mode } & $55^{a}$ & 60 & $50^{a}$ & $68^{a}$ \\
\hline \multicolumn{2}{|c|}{ Std. Deviation } & 14.955 & 10.365 & 14.238 & 9.797 \\
\hline \multicolumn{2}{|l|}{ Variance } & 223.651 & 107.430 & 202.723 & 95.978 \\
\hline \multicolumn{2}{|l|}{ Skewness } & -.172 & .709 & -.523 & -.207 \\
\hline \multicolumn{2}{|c|}{ Std. Error of Skewness } & .427 & .427 & .427 & .427 \\
\hline \multicolumn{2}{|l|}{ Range } & 55 & 42 & 45 & 33 \\
\hline \multicolumn{2}{|l|}{ Minimum } & 30 & 45 & 40 & 62 \\
\hline \multicolumn{2}{|l|}{ Maximum } & 85 & 87 & 85 & 95 \\
\hline \multicolumn{2}{|l|}{ Sum } & 1918 & 1904 & 2071 & 2347 \\
\hline \multirow[t]{3}{*}{ Percentiles } & 25 & 53.75 & 58.75 & 53.75 & 68.00 \\
\hline & 50 & 60.00 & 60.00 & 78.00 & 82.00 \\
\hline & 75 & 77.25 & 67.75 & 82.00 & 86.00 \\
\hline
\end{tabular}

a. Multiple modes exist. The smallest value is shown

Descriptive Statistics

\begin{tabular}{|c|c|c|c|c|c|c|c|c|c|}
\hline & $\begin{array}{c}\mathrm{N} \\
\text { Statistic }\end{array}$ & $\begin{array}{l}\text { Range } \\
\text { Statistic }\end{array}$ & $\begin{array}{l}\text { Minimu } \\
\text { m }\end{array}$ & $\begin{array}{c}\text { Maximu } \\
\mathrm{m}\end{array}$ & $\begin{array}{c}\text { Sum } \\
\text { Statistic }\end{array}$ & Statistic & $\begin{array}{l}\text { Std. } \\
\text { Error }\end{array}$ & $\begin{array}{c}\text { Std. } \\
\text { Deviation } \\
\text { Statistic }\end{array}$ & $\begin{array}{c}\text { Varianc } \\
\text { e }\end{array}$ \\
\hline PretestCG & 30 & 55 & 30 & 85 & 1918 & 63.93 & 2.730 & 14.955 & 223.651 \\
\hline PosttestCG & 30 & 42 & 45 & 87 & 1904 & 63.47 & 1.892 & 10.365 & 107.430 \\
\hline PretestEG & 30 & 45 & 40 & 85 & 2071 & 69.03 & 2.600 & 14.238 & 202.723 \\
\hline PosttestEG & 30 & 33 & 62 & 95 & 2347 & 78.23 & 1.789 & 9.797 & 95.978 \\
\hline $\begin{array}{l}\text { Valid N } \\
\text { (listwise) }\end{array}$ & 30 & & & & & & & & \\
\hline
\end{tabular}

\section{Paired Samples Test}

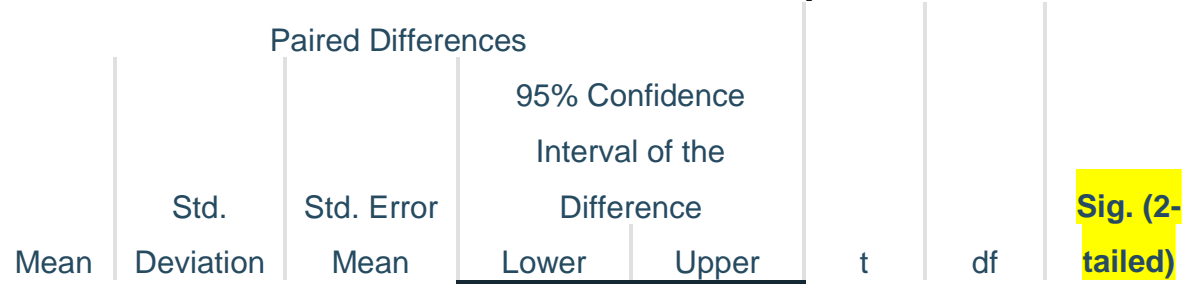




\begin{tabular}{r|r|r|r|r|r|r|r}
\hline .467 & 11.916 & 2.175 & -3.983 & 4.916 & .215 & 29 & .832 \\
\hline-9.200 & 5.182 & .946 & -11.135 & -7.265 & -9.724 & 29 & .000 \\
\hline
\end{tabular}

Based on the table 1, it can be said that there is significance difference in experimental class using visual illustration because the score of significant is lower than $0.05(0.00<0.05)$. It means that the technique is effective in teaching grammar, However, in control group, the significant score is higher than $0.05(0.832>0.05)$. It means that the technique in control group is not effective in teaching grammar in the classroom for students. In short, the technique in experimental group is more effective than the technique in control group.

Table 2

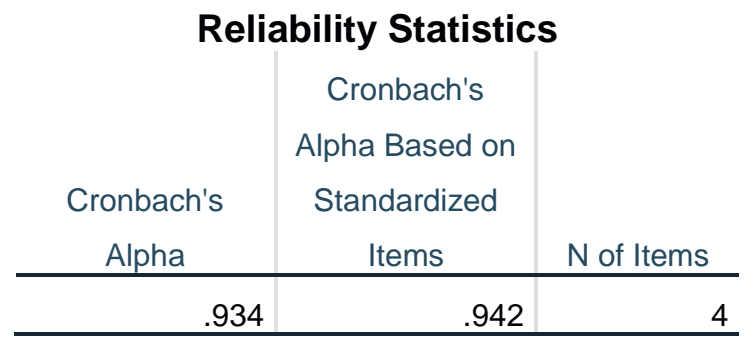

Table 2 shows that the Cronbach's Alpha is 0.934 . It is higher than 0.70. It means that the data has a high reliability.

\section{Interview}

To get more data, the researcher also did interview to know their opinion about grammar teaching itself. The short transcript interview can be seen in sample 1 and 2 below.

Sample 1

Researcher : What do you think about teaching grammar in your class in this semester?

Student 1 : I think it is interesting sir because I am not bored in the classroom. Hmmm......also my ability in grammar improved.

Student 2 : It is fun sir, because my lecturer taught us in interesting way, like show the video, pictures and etc.

Student 3 : Actually it is good sir, unfortunately I did not come for several times because of sick. However, as long as I follow my lecturer's lesson, I can understand esaily about his teaching.

Based on the interview in sample 1, it can be analyzed that all the students give positive response in their lecturer during teaching grammar. As it is in student 1,2 and 3, "I think it is interesting sir because I am not bored.....". "It is fun sir, because my lecturer taught us in interesting way", "Actually it is good sir". Thus, those quotations indicate that the students like learning grammar.

Sample 2

Researcher : How is your grammar ability after your lecturer taught grammar in your class? 
Student 1 : My grammar ability getting improvement even though I need more practice

Student 2 : $\quad$ Eee I think I feel better sir because my mark is better than before

Student 3 : After my lecturer taught me, I think I got a progress sir because I can understand tenses and implement it in writing and speaking although I still did mistakes in grammar, but it was fewer than the previous sir.

Based on the interview in sample 2, it can be said that the students got enhancement in their grammar ability because they could minimize their mistakes in grammar. As student 3 said "After my lecturer taught me, I think I got a progress sir because I can understand tenses and implement it in writing and speaking although I still did mistakes in grammar, but it was fewer than the previous sir". Therefore, it can be concluded that the students could enhance their grammar ability after getting treatment in teaching grammar.

\section{Students' Problems in Learning Grammar}

This second research questions can be illustrated in interview transcript in excerpt 1 below.

Excerpt 1

Researcher: What is your problem in learning grammar 1 ?

Student 1 : I am still confused about the use of tenses sir. For example, when I use to be or auxiliary verb.

Student 2 : My problem is that I do not know differentiate nominal and verbal sentence.

Student 3 : My problems are using simple present tense, simple past tense. I cannot identify irregular verb and I misuse of modal auxiliary.

Student 4 : I have a problem in grammar because I always cannot distinguish between noun and verbal in making a sentence.

Student 5 : I think I am still difficult to implement possessive pronoun and tenses.

Student 6 : My problem is that I have not had enough knowledge about grammar and I am lazy to read and learn sir.

Excerpt 1 show that students have several problems in learning grammar. Those problems are misuse to be or nominal sentence and auxiliary verb or verbal sentence in tenses. As students said "..that I do not know differentiate nominal and verbal sentence, because I always cannot distinguish between noun and verbal in making a sentence". Besides, students had less knowledge about grammar itself, as student said, "My problem is that I have not had enough knowledge about grammar and I am lazy to read and learn sir". Moreover, students had problem in terms of modal auxiliary, as student said, "I misuse of modal auxiliary". Another problem is hard to implement possessive pronoun and tenses, as student said, "...still difficult to implement possessive pronoun and tenses". In brief, the barriers of students in learning grammar are misuse tenses, misuse modal auxiliary, misuse nominal and verbal sentence, pronoun.

\section{The reason Students Faced Grammar Problems}

Based on the interview and observation that had been done by researchers, several reasons why some students faced the grammar problems. The first, students misused nominal sentence and verbal sentence in tenses because the students were not given extra time to ask the questions by the lecturer. It can be proved by the student who said, I cannot ask the question to the lecturer because I am not given a chance to ask because of time limited. The second, the student misused modal auxiliary, irregular verb, and possessive pronoun because they were lazy to learn, read and practice at home, they just learn at campus and forget the lesson. It can be seen in the interview transcript by students who said, I am lazy to learn grammar because it is difficult for 
me and I seldom to read and practice about grammar, hence I had problems in learning grammar. Moreover, several students faced the problems about difficult to memorize the formula or the pattern from the sentence. It can be proved by students who said, ...yes, I got problems in terms of remembering the pattern of the grammar when learning grammar. The last, several students got problem about the time to study because they were all working during studying. Thus, they just learn English at campus. Hence, they sometimes lose concentration. They seldom do their task. It can be proved by student, who said, I have no time to learn grammar outside campus because I have to work to fulfill my family need, thus, I am difficult to practice at home.

\section{Discussion}

The implementation of visual illustration technique in teaching grammar had good response to the students' progress in learning grammar. The students enhanced their grammar's ability after getting treatment from their lecturers. The results of t-test statistic calculation show that Visual Illustration technique is more effective than conventional technique. Besides, the results of mean score also showed that the technique in experimental class is higher than control group namely 78.23 is higher than 63.47. According to Brown (2004), object, charts, written text, or other visual illustration can be used by the English teacher or the lecturer in teaching grammar. Visual illustration could improve the students' ability in learning grammar because the students were given an activity which increased their motivation and ability in learning grammar. For example, the lecturer showed the video as a model in learning simple present tense, so the students would see the video and learn the simple present tense from video. Another example was, the students were given a picture and the students were asked to write down the story which contains the grammar. Valderber, Sellnow \& Valderber (2012) stated that giving a model, such as video modelling can increase the students' ability in learning because they saw the model in the video. Ur (2012) also stated that learning grammar needs more logical and needs approriate strategy or techniques. The technique can be from chart, picture, written text, oral and other strategies. Those can be called as visual illustration because we learn grammar by looking them. Therefore, visual illustration can be used to improve the students' grammar ability.

However, several students still faced problems in learning grammar during the implementation of visual illustration technique. The problems were still about misusing to be and auxiliary verb in tenses, lack of grammar knowledge, lazy to learn, misusing nominal, verbal sentence, pronoun and modal auxiliary and problem of teacher's way in teaching. Those problems were in line with the previous studies by Widianingsing \& Gulo (2016) and Ameliani (2019) who stated that the major kinds of errors made by the students are related to plural markers, articles, verbs, and tenses. Iqbal, Akbar \& Ahmad (2017) also found that not only the lack of knowledge about grammar becomes the problem, but also the way the teacher uses the strategy in the classroom, some students did not like if the teacher cannot maximize in teaching grammar. Moreover, the lack of teacher or lecturer in grammar can be one of the problems; hence the students were difficult to understand the grammar lesson. Another study by Effendi, Rokhyati, Rachman, Rakhmawati, Peritwi (2017) also found the problem of students in learning grammar namely mother tongue use, teachers' aspect, students' aspect and timing. Handayani \& Johan (2018) said that the majority problem faced by students is tenses. This findings were little bit different from the result of this study, where in this result, the researcher did not find mother tongue use. 
Moreover, several students proposed their reasons why they faced the problems. The result showed that they were lazy to learn grammar because they think that it was difficult for them. In this case, they did not have enough knowledge about grammar, The next reason is that students sometimes were not given an opportunity to ask because the time of learning grammar was limited in the classroom. Hence, it influenced their understanding about grammar. This finding was in line with Ameliani (2019) who stated that some factors who can causes the students' problems in learning grammar namely negative interlanguage and intralingual transfers in the forms of adverb interference, copulative verb interference, word-order interference, tense-form interference, overgeneralization, ignorance of rule restriction, and incomplete application of rules. Moreover, Widianingsing \& Gulo (2016) stated that the reason students had problems in learning grammar can be caused by several factors, such as poor knowledge, time for learning, lazy to read and less learning sources.

\section{CONCLUSION}

In conclusion, visual illustration can be used for the lecturer as alternative way to teach grammar because it can enhance the students' grammar ability. Furthermore, the students had positive perception toward the implementation of teaching grammar with visual illustration. Moreover, students faced several problems in learning grammar, such as misusing tenses, pronoun and modal auxiliary. Besides, students were less grammatical knowledge and other problems mentioned in the results. Several reasons students got the problems were because of students' factor, lecturer factor and time limitation in learning grammar.

\section{ACKNOWLEDGMENTS}

This article is funded by the researcher itself.

\section{REFERENCES}

Al-Mekhlafi. A. M., \& Nagaratnam, R.P. 2011. "Difficulties In Teaching and Learning Grammar in an Efl Context". International Journal of Instruction. 4(2), 13081470.www.e-iji.net p-ISSN: 1694-609X.

Ameliani, A.N. (2019). Students' difficulties in grammar of seventh grade junior high school 1 Magelang. Proceeding of 1 st Conference of English Language and Literature (CELL). $1(1), 1-8$.

Ary, D., Jacobs, L. C., Sorensen, C. K., Walker, D. A., \& Razavieh, A. (2010). Introduction to research in education. In Measurement (8th ed., Vol. 4, Issue 43). Wadsworth, Cengage Learning. https://doi.org/10.1017/CBO9781107415324.004

Brown. D. (2004). Teaching by Principles: An Interactive Approach to Language Pedagogy. Pearson Education. USA.

Creswell, J. W.(2014). Research Design: Qualitative, Quantitative and Mixed Method Approaches $4^{\text {th }}$ Edition. New York: SAGE Publication Inc.

Effendi, M.S., Rokhyati, U., Rachman, U.A.M., Rakhmawati, D.A., Peritwi, D. (2017). A study on grammar teaching at an English education department in an EFL context. International Journal on Studies in English Language and Literature (IJSELL). 5(1), 42-46.

Fraenkel, J., R., Wallen, N. E., and Hyun, H. H. (2012). How to design and evaluate research in education 8th edition. New York: McGrow-Hill Companiens Inc.

Handayani, N.D., \& Johan, M. (2018). Problem faced in grammar of EFL students. Open Journal System: Khasana Ilmu Berazam. 1(2), 33-41. 
Heigham, J. and Robert.A. C. (eds). (2009). Qualitative research in applied linguistics: a practical introduction. London: Palgrave Macmilan.

Iqbal, M. K., Akbar, M., \& Ahmad, M. (2017). Problems in teaching grammar to English learners at secondary level. Asian Innovative Journal of Social Sciences \& Humanities (AIJSSH). 1(1), 55-65.

Nazari, A., \& Allahyar, N. (2012). Grammar Teaching Revisited: EFL Teachers between Grammar Abstinence and Formal Grammar Teaching. Australian Journal of Teacher Education, 37(2). http://dx.doi.org/10.14221/ajte.2012v37n2.6.

Singh, R. (2011). Controversies in Teaching English Grammar. Academic Voices, Multidisciplinary Journal. 1(1), 56-60.

Sinka, M. (2009). klassi eesti keele 2008. aasta riikliku tasemetöö analüüs, [Online], Available:http://www.ekk.edu.ee/vvfiles/0/6_\%20klassi_eesti_\%20keele_\%20tasemet_ 366_366\%202008\%20anal_374_374sx.pdf [20 March 2013].

Thornbury, S. (1999). How to teach grammar. Harlow: Pearson Education.

Uibu, K., \& Liver, M. (2015). Students' Grammar Mistakes and Effective Teaching Strategies. International Journal of Teaching and Education, Vol. III(1), pp. 70-87., 10.20472/TE.2015.3.1.006.

Ur, P. (2012). A Course in Language Teaching Practice. Cambridge University:New York.

Widianingsih, N.K.A., \& Gulo, I. (2016). Grammatical Difficulties Encountered by Second Language Learners. Proceeding of the Fourth International Seminar on English Language and Teaching. 4(2), 2. 